AperTO - Archivio Istituzionale Open Access dell'Università di Torino

A review of the nature, role and control of lithobionts on stone cultural heritage: weighing-up and managing biodeterioration and bioprotection

This is a pre print version of the following article:

Original Citation:

Availability:

This version is available http://hdl.handle.net/2318/1755615

since 2020-09-17T13:51:03Z

Published version:

DOI:10.1007/s11274-020-02878-3

Terms of use:

Open Access

Anyone can freely access the full text of works made available as "Open Access". Works made available under a Creative Commons license can be used according to the terms and conditions of said license. Use of all other works requires consent of the right holder (author or publisher) if not exempted from copyright protection by the applicable law. 


\section{The nature, role and control of lithobionts on stone cultural heritage: weighing-up and managing biodeterioration and bioprotection}

Sergio Enrico Favero-Longo, ${ }^{1, *} \&$ Heather A Viles ${ }^{2}$

${ }^{1}$ Università degli Studi di Torino

Dipartimento di Scienze della Vita e Biologia dei Sistemi

Viale Mattioli 25, 10125 Torino, Italy

Tel. +390116705972

Fax +390116705962

sergio.favero@unito.it

orcid.org/0000-0001-7129-5975

${ }^{2}$ University of Oxford,

School of Geography and the Environment

South Parks Road, Oxford, OX1 3QY, Oxford, UK

Tel: +44 1865285070

heather.viles@ ouce.ox.ac.uk

orcid.org/0000-0002-2444-1295

*corresponding author: sergio.favero@unito.it

\section{Acknowledgements}

The authors thank Prof. em. Ian Maddox for the kind invitation to contribute this review article.

SEFL and HV are also grateful to institutions and authorities which allowed their research work in

the following heritage sites represented in Figures 1 and 3: Residences of the Royal House of Savoy

(Polo Museale del Piemonte, Italy); Archaeological Park of Seradina and Bedolina (Comune di

Capo di Ponte, Valle Camonica, Italy), Soprintendenza Archeologia della Lombardia (Milano,

Italy); Gardens of Boboli (Gallerie degli Uffizi, Italy); the graveyard of Gressoney-La-Trinité

(Comune di Gressoney-La-Trinité, Italy); North Grotto Temple (Dunhuang Academy, China).

SEFL also thanks prof. Rosanna Piervittori, dr. Enrica Matteucci (Università di Torino), dr. Ada

Roccardi (Istituto Superiore per la Conservazione e il Restauro, Roma), and all the colleagues of the

Working Group for Cultural Heritage of the Italian Lichen Society for many stimulating discussions on lichens and other lithobionts in the last two decades. 
54

\section{Abstract}

Lithobionts (rock-dwelling organisms) have been recognized as agents of aesthetic and physicochemical deterioration of stonework, and removal of microorganisms from cultural heritage stone surfaces (CHSS) is widely considered a necessary step in conservation interventions. On the other hand, lithobiontic communities can help integrate CHSS with their environmental setting and enhance biodiversity. Moreover, in some cases bioprotective effects have been reported and even interpreted as potential biotechnological solutions for conservation.

This paper reviews the plethora of traditional and innovative methodologies to characterize lithobionts on CHSS in terms of biodiversity, interaction with the stone substrate and impacts on durability. In order to develop the best management and conservation strategies for CHSS, such diagnosis should be acquired on a case-by-case basis, as generalized approaches are unlikely to be suitable for all lithobionts, lithologies, environmental and cultural contexts or types of stonework.

Strategies to control biodeteriogenic lithobionts on CHSS should similarly be based on experimental evaluation of their efficacy, including long term monitoring of their effects on bioreceptivity. This review examines what is known about the efficacy of control methods based on traditional-commercial biocides, as well as those based on innovative application of substances of plant and microbial origin, and physical techniques. A framework for providing a balanced scientific assessment of the role of lithobionts on CHSS and integrating this knowledge into management and conservation decision-making is presented.

Keywords: biocide, biodiversity, biofilm, bioreceptivity, conservation of cultural heritage stone surfaces, stone cleaning, stone durability 


\section{The issue of lithobionts on the stone cultural heritage: an introduction}

The preservation and transmission to future generations of stone cultural heritage (objects, buildings and sites carved in, or built from, stone), including rock art, archaeological and historical monuments and artistic stonework, are globally shared and signed duties, which need to be combined with the protection and conservation of natural heritage (Convention Concerning the Protection of the World Cultural and Natural Heritage 1972). As with other global issues in today's changing world, scientific advances can inform effective and environmentally conscious management, based on correct identification of threats, and development of sustainable solutions (Ferretti and Comino 2015; Charter and Tischner 2017). The growth of lithobionts (i.e. rockdwelling organisms) on cultural heritage stone surfaces (CHSS; Fig. 1) has long been associated with biodeterioration, which can be defined as any undesirable change in the properties of a material caused by the vital activities of organisms (Hueck 1965), and recognized as a threat to conservation (Caneva et al. 2008). This is not surprising given widespread evidence of biogeophysical processes (such as mechanical fracturing and disruption of rocks and minerals by living structures) and biogeochemical processes (chemical destabilization and compositional change of rocks and minerals by metabolic processes and products), which are vital to pedogenesis (Silverman 1979; Totsche et al. 2010). Plenty of field and experimental data demonstrate rock weathering by macro- and micro-organisms (bioweathering), such as vascular plants (Pawlik et al. 2016) and bryophytes (Ricci and Altieri 2008), lichenized- (Seaward 2015) and non-lichenized fungi (Gadd 2017), photo- (Albertano 2012) and chemo- lithotrophic bacteria (Mapelli et al. 2012). Coupled with the desire to remove lithobionts from heritage stone surfaces for aesthetic reasons (because they can produce unsightly discoloration and obscure important carved details), such biodeteriorative roles strengthen the case for conservation interventions (Pinna 2017).

On the other hand, lithobiontic communities have also been seen as enhancing biodiversity, and in some cases bringing positive aesthetic characteristics to CHSS (see section Factors affecting the opportunity to remove (or preserve) lithobionts). Furthermore, the last two decades have seen an 
increasing interest in whether lithobiontic communities can in some circumstances also act as a bioprotective layer, covering stone surfaces and limiting weathering processes driven by abiotic factors, such as meteorological forces and air pollutants (Carter and Viles 2005; McIlroy de la Rosa et al. 2012). Such findings, mixed with advances in investigating biomediated approaches (microbial biocementation) which can promote the consolidation of stone (Fernandes 2006; Wang et al. 2016; Shraddha and Darshan 2019), have contributed to the recent proposal that bioprotection of buildings and cultural heritage by lithobionts may be a sustainable strategy (Gadd and Dyer 2017). It is important not to see contrasting research findings on biodeterioration and bioprotection as conflicting positions, as they likely represent different aspects of complex interactions within and between natural or cultural heritage ecosystems (see section Biodeteriorative and/or bioprotective effects). Misunderstandings on this point may indeed critically impact decisions on the management of lithobionts on CHSS, which should not be based on generalized views of biodeterioration vs bioprotection as ideologically opposed 'schools of thought', but on diagnostic analyses targeting each case. Advances in molecular, microscopy and spectroscopy methods since the 1990s have strongly improved the likelihood of characterizing the diversity of lithobionts on CHSS, and their related biogeophysical and biogeochemical processes (Piñar and Sterflinger 2018; Sanmartín et al. 2018; Schröder et al. 2019). In the following section, colonization patterns and physico-chemical processes driven by the major groups of lithobionts are exemplified, together with a critical evaluation of what diagnostic approach is required to reliably unveil their biodeterioration and/or bioprotection potential on CHSS. In the second part, approaches to manage lithobionts on CHSS are outlined, and a potential decision framework based on experimental assessment and monitoring of both the roles of lithobionts and the efficacy of control strategies is introduced. 
Stone bioreceptivity and biogeophysical and biogeochemical impacts of lithobionts

Natural rock surfaces and CHSS provide interfaces between geological materials, air and water which are invariably colonised by lithobionts (Gorbushina and Broughton 2009). Intrinsic physicochemical properties of stone materials (e.g. surface roughness, porosity, mineral, composition) are the primary factors determining their bioreceptivity, i.e. their aptitude to be colonized by living organisms (Guillitte 1995; Miller et al. 2010). The rate of supply of biological particles, usually resistant structures (spores, pollens) dispersed as bioaerosol, is the main complementary factor needed to start and support colonization dynamics (Mandrioli et al. 2003). Other extrinsic factors, such as climatic conditions and the availability of organic nutrients, influence the composition and structure of lithobiontic communities on CHSS, with their network of nutritional interactions (autotrophs/producers; heterotrophs/destroyers and consumers) (Caneva et al. 2008).

An index to quantify bioreceptivity has been proposed to evaluate the performance of any construction material and support management decisions in the ornamental stone industry which can be applied to CHSS (Vázquez-Nion et al. 2018). In the suggested protocol, the growth of a standard photoautotrophic community (bryophyta, green algae, cyanobacteria) on coupons of different lithologies is compared by fluorimetry (to quantify the amount of chlorophyll $a$ ) and spectrophotometry (to quantify colour change. Such an approach reflects the fact that aesthetic appearance (colour, visibility of artistic details) is important for perceptions of the value of CHSS (Brimblecombe and Grossi 2005). On the other hand, such an index does not take account of the three-dimensional phenomenon of lithobiontic colonization of CHSS, in which the hidden dimension, below the surface, represents the major interface between biotic and mineral components.

Across a range of spatial scales, higher plants, bryophytes, lichens and microorganisms anchor or adhere to mineral substrates, including CHSS, in order to provide stability, exploit water and/or nutrients, and as a consequence modify the physico-chemical properties of the substrates. The root 
systems of woody plants growing directly on pavements or masonries, and, in the case of tree, in proximity to building foundations and hypogean structures, can exert mechanical forces and cause superficial and structural damage, especially in archaeological sites (Caneva et al. 2009; Bartoli et al. 2017). The penetration of slender rhizoids and protonemata of mosses (even though not enforced by lignin) have been related to mechanical damage of mosaics and wall paintings (Saiz-Jimenez et al. 1991; Ricci and Altieri 2008). In the case of lichens (Fig. 2 a-d), the penetration of mycobiont hyphae beneath epilithic crustose thalli, and of the anchoring points of rhizinae and haptera of foliose and fruticose lichens, respectively, has been microscopically characterized within many different stone materials (de los Ríos and Ascaso 2005; Salvadori and Casanova-Municchia 2016). Different patterns of penetration are found depending on the mineralogical and microstructural features of different lithologies, and the species involved, with hyphal organization, spread, and depths ranging from a few microns to several millimeters (Favero-Longo et al. 2005; Scarciglia et al. 2012; Sohrabi et al. 2017). Moreover, some lichen species display an endolithic habit, with the thallus (including the photobiont layer) growing entirely within the rock substrate, exploiting internal cracks (chasmo-endolithic) or intrinsic porosities (crypto-endolithic), or actively dissolving minerals (eu-endolithic) (Pinna et al. 1998; Casanova-Municchia et al. 2014; Favero-Longo et al. 2015).

Similar ranges of growth, from fully epilithic to fully endolithic, also characterize autotrophic and heterotrophic microorganisms usually organized as biofilms, which are adapted to every kind and level of environmental stress in terms of temperature, water and nutrient availability, and solar irradiation (Gorbushina and Broughton 2009). Archaea, bacteria and eukaryotic microbes, as nonlichenized fungi, widely live embedded in an extracellular matrix of biopolymers, usually known as as EPS (Extracellular Polymeric Substances), which is dominated by polysaccharides, but also contains (glyco-)proteins, glycolipids and DNA (Flemming et al. 2007, 2017). High hydration of EPS makes biofilms functionally active and resistant environments, favouring the nutrition, communication and defence of microbes, and also drives their physico-chemical interactions with 
the substrate. Cyclic hydration and dehydration of biofilms cause volume changes and, as a consequence, pressures at their points of adhesion, causing disaggregation and detachments (Negi and Sarethy 2019). A similar mechanical action is exerted by mosses and lichens, whose water status varies passively with environmental conditions (poikilohydric organisms; Seaward 2015).

The covering of rock surfaces and CHSS by coloured dark patinas and thalli also influences the thermal behaviour of the surface and consequent physical stress (Garty 1990; Carter and Viles 2004). In parallel, water availability at the lithobiont-rock interface favours the mobilization of metabolites and mineral ions, supporting chemical modification and sometimes dissolution of the original mineral constituents and the precipitation of new (bio-)minerals (Banfield et al. 1999). Accordingly, protons excreted by plant root tips induce cationic exchange and contribute to ion mobilization from the contacted minerals, and their chemical modification (Caneva et al. 2008). Bryophytes, like algae and cyanobacteria, can favour the precipitation of carbonates, as a consequence of photosynthetic removal of $\mathrm{CO}_{2}$ and their ability to solubilize and bind $\mathrm{Ca}$, a phenomenon reported for natural springs, but also for fountains and monuments in humid regions (Bolívar and Sánchez-Castillo 1997; Ortega-Morales et al. 2000; Crispim and Gaylarde 2005; Ricci and Altieri 2008). Several lichenized and non-lichenized fungi secrete a large variety of primary and secondary metabolites with acidic and chelating functions, supporting acidolysis and complexolysis (Piervittori et al. 2009; Gadd 2017). The biomineralization at the lichen-substrate interface of different oxalates (e.g. Ca-, $\mathrm{Mg}$-, Fe-, Mn-oxalate), depending on the rock metal contents, has frequently been cited as evidence of the direct influence of the mycobiont secretion of oxalic acid on colonized surfaces (Adamo and Violante 2000; Chen et al. 2000; Gadd et al. 2014). In particular, calcium oxalates (whewellite and weddellite) have been reported on a wide range of lithologies, even those poor in $\mathrm{Ca}$, because of their very low solubility in comparison with other oxalate species (Fig. 2 e-f; Favero-Longo et al. 2005), and they are often found on CHSS colonized by certain lichens (Edwards et al. 2003; Pena-Pozo et al. 2018; Tonon et al. 2019). The insolubility of Ca-oxalates also accounts for their long persistence on CHSS, where their biological origin has 
been suggested as an alternative to a chemical origin (e.g. due to degradation of restoration products) even in the absence of viable lithobiontic communities (Caneva et al. 1993). Mineral leaching by other fungal primary metabolites (e.g. citric and malic acids) has also been documented (Wei et al. 2012; Sazanova et al. 2016), but they have generally received less attention in the field of CHSS in comparison to oxalates because of the absence of clear or persistent traces. Mineral leaching activity by complexation has also been reported for some depsides, depsidones and pulvinic acid derivatives (secondary metabolites exclusive to lichens) although their low solubility may limit their impact (Ascaso et al. 1976; Haas and Purvis 2006; Favero-Longo et al. 2013). All these metabolites, as well as the involvement of EPS, seem to contribute to the weathering of silicate minerals into clays, as TEM investigations have showed for the lichen-driven vermiculization of biotite and other cases (Cuadros 2017), and in several cases to the dissolution of carbonates (Pinheiro et al. 2019).

Different processes need to be invoked to explain the euendolithic behaviour of certain lichen species, as they do not secrete either oxalic acid or the above mentioned lichen secondary metabolites (Pinna et al. 1998). In some cases respiration-induced acidification of the substrate has been shown to be sufficient to provoke pitting activity (formation of sub-millimetric cavities on the surface) (Weber et al. 2011), but the involvement of siderophore-like compounds has also been hypothesized, as these complexing compounds, involved in iron nutrition, also scavenge calcium if iron availability is low (Favero-Longo et al. 2011). Similarly to endolithic lichens, microcolonial fungi $(\mathrm{MCF})$, which are a group of fungi tolerant of the extreme stress of exposed substrates and thus colonizing bare rock surfaces, including CHSS (Sterflinger 2010), are responsible for dissolution and pitting phenomena on carbonate and silicate rocks, but the processes responsible still need to be clarified (De Leo et al. 2019). The rigidity of their cell wall due to melanin deposition has been related to their penetration ability (Sterflinger and Kumbein 1997), but ion mobilization by chelating molecules (Favero-Longo et al. 2011) and/or corrosive EPS containing pullulan and galactofuromannan as the main constituents (Breitenbach et al. 2018) may be involved. 
212 The strong negative charge of cyanobacterial EPS, due to uronic acids and sulphate groups, also contributes to the dissolution of cations from colonized substrata and their microbial adsorption (Bellezza et al. 2006; Albertano 2012). Sulfuric, nitrous and nitric acids are released by chemolithotrophic (sulphur-oxidizing, nitrifying) bacteria and (ammonia-oxidizing) archaea, through enzyme catalyzed oxidation of inorganic compounds, such as ammonia, elemental sulphur and hydrogen sulphide, and are likely to have impacts on CHSS (Warscheid and Braams 2000; Zhang et al. 2019).

\section{Biodeteriorative and/or bioprotective effects}

All the above-mentioned (and many other) patterns of lithobiont-substrate interactions, in terms of biogeophysical and biogeochemical processes, have been increasingly detailed in the last two-three decades and supported by a huge number of study cases, including CHSS. This has certainly helped clarify the worldwide distribution and impacts of certain phenomena, but, in some cases, experimental evidence obtained by advanced, $21^{\text {st }}$ century technologies simply confirms early insights dating back to the first part of the $20^{\text {th }}$ century and before. For example, early descriptions and accurate microscopic observations of lichen growth within rocks (Gümbel, 1856; Fry 1924 1927), as well as the recognition of lichen-driven chemical processes due to oxalic acid secretion and/or a respiration-induced acidification (Slater, 1856; Uloth 1861; Sollas, 1880; Smith 1921), provided convincing evidence of lichen biogeophysical and biogeochemical processes and are still widely quoted today. However, the advent in recent years of a wide range of portable, nondestructive methods now permits sophisticated measurements (such as spectroscopic analysis) which can characterize the presence of metabolites and biominerals on/within CHSS in situ (Maguregui et al. 2012; Costantini et al. 2018). Advances in molecular biology, and in particular the diagnostic power of next-generation sequencing, have highlighted the huge variety of microorganisms which can occur together on and beneath rock surfaces and CHSS, only partially 
detectable by microscopy and culturing approaches, and not always directly related to more visible surface colonizers (Bjelland et al. 2011; Piñar and Sterflinger 2018; Trovão et al. 2019).

On the other hand, whilst the observation and detection of (micro-)organisms, their structures and metabolites, or their molecular signs, certainly implies present or past interactions with rock substrates and CHSS, it does not necessarily mean that they play a biodeteriorative role as is often routinely thought. In this context, DNA-metabarcoding analyses particularly need careful evaluation to decipher which microorganisms are growing on and actively interacting with the substrates, and which simply occur as past traces, dormant structures or episodic (dust) contaminants (Marvasi et al. 2019). Implementation of molecular analysis pipelines, including the storage and effective access of datasets dedicated to the biodeterioration research area, also represent an ongoing challenge (Sterflinger et al. 2018).

Whilst there is incontrovertible evidence of mineral disintegration, chemical modification and leaching by lithobionts, other studies have highlighted bioprotective activities, which were also hypothesized many years ago (Krumbein 1968). Such hypotheses were based on early macroscopic observations of differential erosion rates with and without lithobionts, suggesting an umbrella-like protective effect (Mottershead and Lucas 1990; Özvan et al. 2015). Such interpretations of lithobionts as forming a physical barrier against other weathering factors have been supported by the quantification of lower solutional weathering from lithobiont (lichen)-covered limestone slates in comparison with uncolonized controls after 1 year of exposure in the humid climate of Ireland (McIlroy de la Rosa 2014). Ivy (Hedera helix) has been found to also have an umbrella-like impact and protect historic limestone walls from pollutants (which can lead to soiling and deterioration) (Sternberg et al. 2011). Additionally, experimental studies illustrate that Hedera helix can also protect vulnerable historic stone walls from freeze-thaw damage through modifying microclimatic conditions (Coombes et al. 2018). In drier climates, rock surface microorganisms have also been demonstrated to be chemically involved in the development of rock coatings, which stabilize the rock surfaces and contribute to their long term preservation (Taylor-George et al. 1983; Dorn 2013). 
Nanometer-scale transport of Fe and Mn accumulated in bacterial sheaths and fixed on clay minerals contributes to the polygenetic formation of rock varnish (Dorn 2013). In arid Jordan, biofilms of cyanobacteria and fungi have been shown to contribute to case-hardening of sandstone by aiding cementation (Viles and Goudie 2004), and in cold arid central Antarctica, endolithic lichens and their EPS have been found to biomineralize iron oxides (Guglielmin et al. 2011). Such effects are also found in wetter climates, for example in the UK where the deposition by epilithic lichens of silica-rich layers within cracks and along mineral boundaries has been observed on granite outcrops alongside biophysical and biochemical weathering impacts (Lee and Parsons 1999). Biomineralization of oxalates has also been considered to produce a potential protective shield against abiotic weathering agents, such as wind and runoff (Souza-Egipsy et al. 2004), and Ca-oxalates have often been proposed as producing potentially protective coatings for CHSS (e.g. Rampazzi 2019).

Multiple biodeteriorative and bioprotective roles of lithobionts have often been proposed. A notable example is the analysis of roles of the lichen Verrucaria rubrocincta on caliche plates in the Sonoran desert (Bungartz et al. 2004; Garvie et al. 2008): simultaneous biodeterioration of the rock substrate and a counterbalancing biomineralization of a upper protecting layer of fine-grained micrite have been recognized and characterized by isotopic analyses. Similarly, calcite dissolution and biomineralization of neoformed calcite around hyphae have been described for non-lichenized fungi (Fomina et al. 2010). Such recognition of both deteriorative and protective effects of lithobionts, and a deep evaluation of the prevailing process, may become crucial in future studies of lithobionts on CHSS (Bartoli et al. 2014). Observations of lithobiont (lichen) communities on tuff churches in Cappadocia showed the deteriogenic activity of penetrating hyphae, whilst some bioprotective effects were simultaneously envisaged, leaving uncertainty about whether or not the growths should be removed (Casanova-Municchia et al. 2018). Such a case study exemplifies the need for case-specific information on the multiple interactions of lithobionts and CHSS, their spatial patterning and their persistence over time, but also on their actual influence on stone durability, 
before appropriate management decisions can be made. Indices to evaluate and quantify the potential biodeteriogenic impact of plants (Signorini 1996), lichens (Gazzano et al. 2009) and microorganisms (Gazzano et al. 2011) have been proposed, but are more oriented to a comparative evaluation of the degree of physico-chemical interaction of different species with the substrate, rather than to quantitatively evaluate their impact on the CHSS (Pinna 2014). As a framework proposal, Table 1 summarizes a range of biodeteriorative and bioprotective roles reported for various types of lithobiontic organisms. It is worth remarking that each (potential) role has to be considered species-specific and cannot be generalized for all the members of each group; moreover it also depends on the lithology and the environmental conditions (see the next sub-section).

\section{Lithobionts and stone durability}

Biodeteriorative and bioprotective processes may or may not balance out, and thus produce complex impacts on the intrinsic stone properties relevant for durability, which can be defined as the capacity of a building material to maintain its size, shape, strength and aesthetic appearance over time (Bell 1993). In particular, knowledge of lithobiont-rock interactions should be combined with quantitative investigation of their impacts on petrophysical properties, including porosity, presence of swelling clay minerals, compactness, water absorption, presence and distribution of anisotropies, compressive strength, and surface hardness (Molina et al. 2013; Wilhelm et al. 2016). Relatively few studies have yet been made of the impacts of lithobionts on durability and resilience of CHSS, although some research has focused on (bio-)geomorphological studies of natural rock outcrops (Viles 2019). The results seem to depend strongly on lithology. For example, lichen colonization has been found to correlate with surface hardening and a reduction of water absorption on tuff (Garcia-Vallès et al. 2003), with a reduction of surface hardness on gneiss (McCarroll and Viles 1995; Favero-Longo et al. 2015), and with variable patterns of surface hardening or softening, and increased water absorption after the scraping of thalli from the surface on limestone (Morando et al. 2017). Such variability suggests the need for tailored investigations to cover a range of 
lithologies, different lichen species, and other, even more overlooked, lithobionts. Experimental datasets are needed to test conceptual models on the balance between biodeterioration and bioprotective processes and the net impact of lithobionts (lichens, in particular) on stone surfaces (McIlroy de la Rosa et al. 2012). In this regard, one particularly important future research direction is elucidating the impact of lithobionts on their substrate beyond their life-span. Surfaces once covered by lithobionts which have been removed by conservation interventions, or have simply died, may indeed display a long term protection effect due to past biogeochemical processes (e.g. protection by a biomineral deposit, cementation, pore-filling by biogenic silica or varnish). Conversely, such surfaces might also be more prone to disintegration following the loss of biological structures which bound the disentangled mineral fragments. The latter scenario appears particularly critical where stone surface details are a crucial component of the heritage values, as in the case of carved rock-art (Tratebas 2004; Favero-Longo et al. 2019).

Developments in laboratory experiments using cultured model lithobiontic organisms, genetically modified lineages, and the combination of closed and open experimental systems provide useful new approaches to disentangling the impacts of lithobionts on CHSS. For example, several studies have cultivated lithobionts on stone coupons and evaluated their impact on stone properties relevant for durability (Favero-Longo et al. 2009; Villa et al. 2015; Pokharel et al. 2017; Seiffert et al. 2016). In this context, it is very important to standardize protocols used in the characterization of biodeteriorative (and bioprotective) processes, using approaches such as microscopic, spectroscopic, culture-based, and 'omics'methods, in order to make scientific data truly comparable and offer more reliable support for management decisions (Pinna 2014; Sterflinger et al. 2018). Research on lithobiontic impacts on CHSS should also consider predicted impacts of climate change on lithobiont colonization and growth (Davidson et al. 2018). Changes in temperature and precipitation regimes, beyond their direct impact on CHSS, have been hypothesized to affect lithobiont communities, causing potential shifts from biodeterioration to bioprotective impacts, and vice versa (Viles and Cutler 2012; Fatorić \& Seekamp 2017). As an example, Gómez-Bolea et al. 
341 (2012) predicted that lithobiontic biomass on CHSS should increase in northern Europe whilst 342 decreasing in southern Europe because of contrasting trends in precipitation. Recent laboratory 343 experiments simulating changing water regimes and increased $\mathrm{CO}_{2}$ concentrations have confirmed 344 the suggested impacts on biofilm composition and a shift towards biodeterioration effects (Prieto et 345 al. 2020). From a different point of view, subaerial biofilms have also been noted as potentially 346 important climate regulators, as agents of carbon sequestration, biogeochemical cycles and 347 elemental transformations (Villa et al. 2016).

\section{Approaches to managing lithobionts on CHSS}

\section{Factors affecting the opportunity to remove (or preserve) lithobionts}

Aspects of culture and tradition have shaped and continue to shape perceptions of the growth of lithobionts on CHSS. Ruins covered by plants and other lithobionts, recognized as evidence of natural decay, are a symbol of the European Romantic taste of the $19^{\text {th }}$ century (Stanford 2000; Huyssen 2006). Similarly, an abundance of lithobionts on some types of heritage sites, such as a Celtic graveyard or a Shinto shrine, can be seen in a positive light today, especially in places where local tradition tends to appreciate, rather than worry about, the merging of CHSS and nature, sharing a common acceptance of human impermanence (Fitzsimons et al. 2012). In most cases, however, alterations in CHSS caused by both biotic and abiotic drivers are considered to be negative, reducing heritage values (Brimblecombe and Grossi 2005; Prieto et al. 2007). As a consequence, removal of lithobionts is usually recognized as a necessary part of conservation interventions (Pinna 2017). However, scientific evidence justifying the removal of lithobionts is often missing.

In order to make more informed decisions about whether to remove (or preserve, or even encourage further) lithobionts, aesthetic evaluations should be combined with data on the impacts of lithobionts on stone durability, based on an analysis of the balance between biodeteriorative and 
bioprotective processes. Such an approach is not in conflict with the priority often given (at least in some countries) to aesthetic evaluations as the basis of management strategies for heritage sites, but enables a broader, more balanced assessments of risks vs benefits. By way of an example, in cases where lithobionts are shown to be predominantly bioprotective, their removal might cause a decrease in durability of CHSS: if the aesthetic damage they cause is more severe, however, and they are removed, strategies to substitute their bioprotective function should be considered. In cases where the aesthetic damage caused by lithobionts is minor, and there is evidence of a bioprotective effect, or of only minor biodeterioration impact, a recommendation could be made to preserve the lithobionts and promote their biodiversity as an additional cultural value of the heritage site (Nimis et al. 1992; Steinbauer et al. 2013). Such an approach may be particularly valuable in the case of CHSS immersed in the natural environment, where the removal of a mature-climactic lithobiontic community, similar to that found on surrounding natural outcrops, is often followed by a rapid recolonization by a simplified community of 'banal' species (Nascimbene et al. 2009). The inclusion of biodiversity in the concept of cultural value of a heritage site agrees with official measures addressing parallel conservation of cultural and natural heritage (e.g. Italian Ministry for Cultural Heritage and Activities 2004: the Italian code of cultural heritage and landscape; UNESCO 2014: Florence Declaration). This may be particularly important for cemeteries, monumental or archaeological sites which are hotspots of lithology or microhabitat diversity and consequently host strongly heterogeneous lithobiontic and plant communities, making them easily accessible to the public (e.g. Nimis et al. 1987; Cicinelli et al. 2018; Löki et al. 2019). In other cases, cultural heritage sites have been clearly identified as preferential sites for the preservation of threatened species or even their re-introduction (Valkó et al. 2018; BLS 2020).

CHSS management should consider all facets of lithobiontic growths before automatically removing lithobionts to conserve and present heritage sites. In all cases, once the decision has been taken to remove lithobionts, the adoption of an effective strategy to clean the CHSS is an absolute priority (Pinna 2017). A major issue for CHSS management is indeed the frequent need to repeat 
treatments to control lithobionts, which in most cases are stress-tolerant (micro-)organisms wellequipped to thwart human attempts to remove them and prevent their regrowth.

\section{Direct and indirect strategies to control lithobionts}

Two main strategies to control lithobionts on CHSS can be distinguished, although their choice should not be considered exclusive and they may be used in combination: first, an indirect approach focused on the control of microenvironmental parameters which favour/allow their growth, and second, direct intervention to remove them from CHSS by physical and/or mechanical and/or chemical methods (Pinna 2017). The first approach is based on the fact that the presence of lithobiontic communities, and, in particular, of certain biodeteriogenic species, depends on the availability of suitable microenvironmental conditions, allowing their establishment, expansion, and reproduction. At any one heritage site, different CHSS often represent diverse ecological microniches, hosting different lithobiontic communities which interact with the substrate and influence its conservation in different ways (Marques et al. 2016; Tonon et al. 2019). Knowledge and monitoring of (micro-)environmental parameters favouring or discouraging lithobiontic communities, and in particular, deteriogenic species, can help recognise and achieve the best conservation solutions (Caneva et al. 2016; Schumacher and Gorbushina 2020). For example, the development of phototrophic biofilms on hypogean CHSS, and even on outdoor surfaces lit by artificial lighting, may be controlled through careful illumination strategies, based on modifying the spectral emission of lamps to affect microbial biomass, colour and EPS production (Albertano and Bruno 2003; Sanmartín et al. 2017). Careful management of higher plants in heritage sites may limit their shading of CHSS, with the consequent increase in humidity, and their supply of nutrients, both of which favour lithobiontic growth (Salvadori and Charola 2011). Such ecologically-based approaches may also be used to choose the most appropriate contemporary building materials (Caneva et al. 2008). 
Direct intervention to clean CHSS should satisfy the main aims of removing the lithobiontic communities and preventing (re-)colonization processes by limiting surface bioreceptivity. These objectives have been variously pursued by combining several mechanical, physical and chemical approaches, already reviewed in detail elsewhere (Pinna 2017). The crucial point is that lithobiontic colonization usually extends well beneath the rock surface and microbial structures generally show a strong capacity to recover from disturbance, and so many cleaning interventions without subsequent biocide treatment are usually followed by rapid recolonization (Sohrabi et al. 2016). Removal by (pressurized) water and brushing may be effective in the case of superficial, subaerial biofilms (Sanmartín et al. 2020), but in other situations they may spread microbial structures, pushing them deeper within the substrate (Pinna 2017). Valuable protocols for the physical removal of lithobionts by laser ablation have been drawn up in the last decade (Sanz et al. 2017), but even the combination of scalpel and laser may sometimes fail to eliminate lithobiontic structures within fissures (Rivas et al. 2018). Similarly, some laser ablation can cause damage to the mineral surface whilst not completely removing the lichens (Pozo-Antonio et al. 2019). As a result of these issues, biocide treatments often precede mechanical removal (Kakakhel et al. 2019). Although many of the more toxic biocides have been banned, safer compounds may have some drawbacks. For example, the effectiveness of quaternary ammonium salts (e.g benzalkonium chloride) to disrupt cell membranes and kill lithobionts has been well demonstrated (Wessels and Ingmer 2013; Vannini et al. 2018; Sanmartín et al. 2020), but their use can promote bacterial adaptation and antibiotic resistance (Kampf 2018; Kim et al. 2018; Poursat et al. 2019). Moreover, their degradation is suspected to contribute to nitrogen supply (Scheerer et al. 2009), thus favouring, rather than preventing, recolonization by aggressive nitrophytic species. Such alarming findings call for caution in biocide application (Stupar et al. 2014) and the need for non-chemical alternatives. As mentioned above, electromagnetic methods, which include laser irradiation as well as UV, microwave and gamma rays (Riminesi and Olmi 2016), are useful but still have limitations for large-scale applications to outdoor CHSS. Alternatively, heat shock treatments have been shown to provide a 
sustainable approach to killing lithobionts such as lichens and mosses (Tretiach et al. 2012; Bertuzzi et al. 2013). These poikilohydric organisms tolerate thermal stress well whilst dehydrated, but do not survive heating to $40-60^{\circ} \mathrm{C}$ for 6 hours when hydrated. Unfortunately, such an approach was less effective against microalgae (Bertuzzi et al. 2017) and the original proposal to exploit solar irradiation to provide the heating may be only suitable under stable weather conditions in warm countries, which limits its applicability. Nevertheless, the combination and improvement of all the cited and other approaches may be expected to shortly produce valuable strategies to moderate the use of biocides.

Whatever the chosen approach to kill lithobionts, it is necessary to monitor its efficacy on the target organisms and the examined CHSS: widely used biocides applied to lichens showed species- and site-specific effectiveness, likely depending on differences in the resistance of symbionts and the influence of different stone surfaces and climate/meteorological conditions (Favero-Longo et al. 2017). Biocides may have different effectiveness against epilithic and endolithic lithobionts (de los Ríos et al. 2012). Moreover, the method chosen to apply biocides, often defined for economic reasons, may strongly influence the final treatment success (Favero-Longo et al. 2017; Matteucci et al. 2019). A preliminary assessment of the viability of targeted microorganisms before and after treatment should be routinely performed by in situ methods, such as fluorimetry (Tretiach et al. 2010).

Although the effective devitalization of lithobionts contributes to keeping CHSS in a "clean" state for longer, (re-)colonization is inevitable (Fig. 3). However, longer term cleaning can be achieved by avoiding the application of compounds after cleaning which may increase bioreceptivity and promote recolonization, as demonstrated in the case of certain consolidants and other restoration products (Barriuso et al. 2017; Favero-Longo et al. 2018). In contrast, some other lithobiont control strategies may contribute to delay recolonization, including the application of photocatalytic nanoparticles (Fonseca et al. 2010; Sierra-Fernandez et al. 2017), and eco-friendly products, as essential oils and other biological substances exerting allelopathic effects (Fidanza and Caneva 
2019). Monitoring programs are increasingly needed to monitor the long-term effectiveness of such approaches, in comparison with the traditional application of biocides following mechanical removal (Bruno et al. 2019; Favero-Longo et al. 2019; Sanmartín et al. 2020). Under certain climate conditions, however, even the most effective strategies may not fully prevent recolonization (Pinna et al. 2018), confirming the necessity of an integrated, site-specific approach (including microclimate control, where possible) to improve the success of management strategies for the conservation of CHSS.

\section{Concluding remarks}

Advances in technology and medical research have provided great tools to diagnose, control and prevent human diseases, and there is a clear integration between scientific research and managing health. This review has outlined that similarly integrated scientific approaches are available to diagnose the role of lithobionts on CHSS and inform management strategies. Lithobiont-CHSS systems display remarkable complexity, encompassing equilibria between lithosphere (i.e. the stone substrate) and biosphere (i.e. the lithobionts), as well as atmosphere/hydrosphere and anthroposphere, which are additional components affecting colonization and weathering dynamics. As in the case of human health, management decisions about the conservation of stone cultural heritage should increasingly take into consideration all the levels of knowledge available (or implementable) to decipher this complexity, and should be based on accurate diagnosis of each situation. Figure 4 presents a framework to include the above-reviewed spheres of investigation required for decision-making on lithobionts and CHSS, with a focus on whether to remove or preserve lithobionts and, if removal is chosen how to choose a suitable control strategy. As Figure 4 demonstrates, there is no 'one size fits all' approach because durability of different CHSS depends on the balance between biodeterioration and bioprotection effects driven by lithobiontic communities, which in turn depends on the species and lithology involved and the (micro)environmental context. Moreover, these same factors (species-lithology-environment) also 
495 determine the effectiveness of control strategies. Thus, whatever the protocol used (innovative or

496 based on traditional techniques) an experimental assessment of its suitability for the CHSS of

497 interest is vital. Funding limitations may discourage scientific investigations on the role of

498 lithobionts and the efficacy of control strategies, but such investigations are vital for cost-effective 499 and environmentally-sustainable management of CHSS in future.

500

501 References

502 Adamo P, Violante P (2000). Weathering of rocks and neogenesis of minerals associated with 503 lichen activity. Appl Clay Sci 16: 229-256

504 Albertano P (2012). Cyanobacterial biofilms in monuments and caves. In: Whitton BA (ed)

505 Ecology of cyanobacteria II. Springer, Dordrecht, pp. 317-343

506 Albertano P, Bruno L (2003). The importance of light in the conservation of hypogean monuments.

507 In: Saiz-Jimenez C (ed) Molecular Biology and Cultural Heritage. Balkema, Lisse, pp. 171-177

508 Ascaso C, Galván J, Rodríguez-Pascual C (1976). Studies on the pedogenetic action of lichen acids.

$509 \quad$ Pedobiologia 16: 321-331

510 Banfield JF, Barker WW, Welch SA, Taunton A (1999). Biological impact on mineral dissolution:

511 application of the lichen model to understanding mineral weathering in the rhizosphere. Proc Natl $512 \quad$ Acad Sci USA 96: 3404-3411

513 Barriuso BC, Botticelli G, Cuzman OA, Osticioli I, Tiano P, Matteini M (2017). Conservation of 514 calcareous stone monuments: Screening different diammonium phosphate based formulations for 515 countering phototrophic colonization. J Cult Herit 27: 97-106

516 Bartoli F, Casanova-Municchia A, Futagami Y, Kashiwadani H, Moon KH, Caneva G (2014).

517 Biological colonization patterns on the ruins of Angkor temples (Cambodia) in the

518 biodeterioration vs bioprotection debate. Int Biodeterior Biodegrad 96: 157-165. 
Bartoli F, Romiti F, Caneva G (2017). Aggressiveness of Hedera helix L. growing on monuments: Evaluation in Roman archaeological sites and guidelines for a general methodological approach.

\section{Plant Biosyst 151: 866-877}

Bell FG (1993). Durability of carbonate rock as building stone with comments on its preservation.

$$
\text { Environ Geol 21: 187-200 }
$$

Bellezza S, Albertano P, de Philippis R, Paradossi G (2006). Exopolysaccharides of two cyanobacterial strains from Roman hypogea. Geomicrobiol J 23: 301-310

Bertuzzi S, Candotto Carniel F, Pipan G, Tretiach M (2013). Devitalization of poikilohydric lithobionts of open-air monuments by heat shock treatments: a new case study centred on bryophytes. Int Biodeterior Biodegrad 84: 44-53.

Bertuzzi S, Gustavs L, Pandolfini G, Tretiach M (2017). Heat shock treatments for the control of lithobionts: A case study with epilithic green microalgae. Int Biodeterior Biodegrad 123: 236-243

Bjelland T, Grube M, Hoem S, Jorgensen SL, Daae FL, Thorseth IH, Øvreås L (2011). Microbial metacommunities in the lichen-rock habitat. Environ Microbiol Rep 3: 434-442

BLS (British Lichen Society) (2020). Churchyard lichen conservation.

https://www.britishlichensociety.org.uk/activities/churchyard-survey/churchyard-lichenconservation. Accessed 02 April 2020

Bolívar FC, Sánchez-Castillo PM (1997). Biomineralization processes in the fountains of the Alhambra, Granada, Spain. Int Biodeterior Biodegrad 40: 205-215

Breitenbach R, Silbernagl D, Toepel J, Sturm H, Broughton WJ, Sassaki GL, Gorbushina AA (2018). Corrosive extracellular polysaccharides of the rock-inhabiting model fungus Knufia petricola. Extremophiles 22: 165-175

Brimblecombe P, Grossi CM (2005). Aesthetic thresholds and blackening of stone buildings. Sci Total Environ 349: 175-189 
Bruno L, Rugnini L, Spizzichino V, Caneve L, Canini A, Ellwood NTW (2019). Biodeterioration of Roman hypogea: the case study of the Catacombs of SS. Marcellino and Pietro (Rome, Italy). Ann Microbiol 69: 1023-1032

Bungartz F, Garvie LA (2004). Anatomy of the endolithic Sonoran Desert lichen Verrucaria rubrocincta Breuss: implications for biodeterioration and biomineralization. Lichenol 36: 55-73

Caneva G (1993). Ecological approach to the genesis of calcium oxalate patinas on stone monuments. Aerobiol 9: 149-156

Caneva G, Bartoli F, Savo V, Futagami Y, Strona G (2016). Combining statistical tools and ecological assessments in the study of biodeterioration patterns of stone temples in Angkor (Cambodia). Sci Rep 6: 32601

Caneva G, Galotta G, Cancellieri L, Savo V (2009). Tree roots and damages in the Jewish catacombs of Villa Torlonia (Roma). J Cult Herit 10: 53-62

Caneva G, Nugari MP, Salvadori O. (2008). Plant biology for cultural heritage: biodeterioration and conservation. Getty Conservation Institute, Los Angeles

Carter NEA, Viles HA (2004). Lichen hotspots: raised rock temperatures beneath Verrucaria nigrescens on limestone. Geomorphol 62:1-16

Carter NEA, Viles HA (2005). Bioprotection explored: the story of a little known earth surface process. Geomorphol 67: 273-281

Casanova-Municchia A, Bartoli F, Taniguchi Y, Giordani P, Caneva G (2018). Evaluation of the biodeterioration activity of lichens in the Cave Church of Üzümlü (Cappadocia, Turkey). Int Biodeterior Biodegrad 127: 160-169

Casanova Municchia A, Percario Z, Caneva G (2014). Detection of endolithic spatial distribution in marble stone. J Microsc 256: 37-45

Charter M, Tischner U (2017). Sustainable solutions: developing products and services for the future. Routledge, London 
Chen J, Blume HP, Beyer L (2000). Weathering of rocks induced by lichen colonization - a review. Catena 39: 121-146

Cicinelli E, Salerno G, Caneva G (2018). An assessment methodology to combine the preservation of biodiversity and cultural heritage: the San Vincenzo al Volturno historical site (Molise, Italy). Biodivers Conserv 27: 1073-1093

Convention Concerning the Protection of the World Cultural and Natural Heritage, 1972. https://whc.unesco.org/en/conventiontext/. Accessed 02 April 2020

Coombes MA, Viles HA, Zhang H (2018) Thermal blanketing by ivy (Hedera helix L.) can protect building stone from damaging frosts. Sci Rep 8: 9834

Costantini I, Castro K, Madariaga JM (2018). Portable and laboratory analytical instruments for the study of materials, techniques and environmental impacts in mediaeval mural paintings. Anal Methods 10: 4854-4870

Crispim CA, Gaylarde CC (2005). Cyanobacteria and biodeterioration of cultural heritage: a review. Microb Ecol 49: 1-9

Cuadros J (2017). Clay minerals interaction with microorganisms: a review. Clay Min 52: 235-262 Davidson TM, Altieri AH, Ruiz GM, Torchin ME (2018). Bioerosion in a changing world: a conceptual framework. Ecol Lett 21: 422-438

De Leo F, Antonelli F, Pietrini AM, Ricci S, Urzì C (2019). Study of the euendolithic activity of black meristematic fungi isolated from a marble statue in the Quirinale Palace's Gardens in Rome, Italy. Facies 65: 18

de los Rios A, Ascaso C (2005). Contributions of in situ microscopy to the current understanding of stone biodeterioration. Int Microbiol 8: 181-188

de los Ríos A, Pérez-Ortega S, Wierzchos J, Ascaso C (2012). Differential effects of biocide treatments on saxicolous communities: case study of the Segovia cathedral cloister (Spain). Int Biodeterior Biodegrad 67: 64-72 
Dorn R (2013). Rock coatings. In: Shroder JF (ed) Treatise on geomorphology. Academic Press, San Diego, pp. 70-97

Edwards HG, Seaward MR, Attwood SJ, Little SJ, de Oliveira LF, Tretiach M (2003). FT-Raman spectroscopy of lichens on dolomitic rocks: an assessment of metal oxalate formation. Analyst 128: $1218-1221$

Fatorić S, Seekamp E (2017). Are cultural heritage and resources threatened by climate change? A systematic literature review. Clim Chang 142: 227-254

Favero-Longo SE, Accattino E, Matteucci E, Borghi A, Piervittori R (2015). Weakening of gneiss surfaces colonized by endolithic lichens in the temperate climate area of northwest Italy. Earth Surf Process and Landf 40: 2000-2012

Favero-Longo SE, Benesperi R, Bertuzzi S, Bianchi E, Buffa G, Giordani P, Loppi S, Malaspina P, Matteucci E, Paoli L, Ravera S, Roccardi A, Segimiro A, Vannini A (2017). Species-and sitespecific efficacy of commercial biocides and application solvents against lichens. Int Biodeterior Biodegrad 123: 127-137

Favero-Longo SE, Borghi A, Tretiach M, Piervittori R (2009). In vitro receptivity of carbonate rocks to endolithic lichen-forming aposymbionts. Mycol Res 113: 1216-1227

Favero-Longo SE, Brigadeci F, Segimiro A, Voyron S, Cardinali M, Girlanda M, Piervittori R (2018). Biocide efficacy and consolidant effect on the mycoflora of historical stuccos in indoor environment. J Cult Herit 34: 33-42

Favero-Longo SE, Castelli D, Salvadori O, Belluso E, Piervittori R (2005). Pedogenetic action of the lichens Lecidea atrobrunnea, Rhizocarpon geographicum gr. and Sporastatia testudinea on serpentinized ultramafic rocks in an alpine environment. Int Biodeterior Biodegrad 56: 17-27 Favero-Longo SE, Gazzano C, Girlanda M, Castelli D, Tretiach M, Baiocchi C, Piervittori R (2011). Physical and chemical deterioration of silicate and carbonate rocks by meristematic microcolonial fungi and endolithic lichens (Chaetothyriomycetidae). Geomicrobiol J 28: 732-744 
Favero-Longo SE, Matteucci E, Ruggiero MG (2019). Caratterizzazione di licheni e patine microbiologiche sulle rocce istoriate del Parco Nazionale delle Incisioni Rupestri di Naquane (Valle Camonica) e metodiche per il loro controllo. Not Soc Lichenol Ital 32: 31

Favero-Longo SE, Turci F, Fubini B, Castelli D, Piervittori R (2013). Lichen deterioration of asbestos and asbestiform minerals of serpentinite rocks in Western Alps. Int Biodeterior Biodegrad 84: 342-350

Fernandes P (2006). Applied microbiology and biotechnology in the conservation of stone cultural heritage materials. Appl Microbiol Biotechnol 73: 291-296

Ferretti V, Comino E (2015). An integrated framework to assess complex cultural and natural heritage systems with Multi-Attribute Value Theory. J Cult Herit 16: 688-697

Fidanza MR, Caneva G (2019). Natural biocides for the conservation of stone cultural heritage: A review. J Cult Herit 38: 271-286

Fitzsimons A, Morrissey S, Woods J (2012). Between East and West. In: De Angelis I. (ed) The Japanese effect in contemporary Irish poetry. Springer, Berlin, pp. 138-158

Flemming HC, Neu TR, Wingender J (2017). The perfect slime: microbial extracellular polymeric substances (EPS). IWA publishing, London

Flemming HC, Neu TR, Wozniak DJ (2007). The EPS matrix: the "house of biofilm cells". J of Bacteriol 189: 7945-7947

Fomina M, Burford EP, Hillier S, Kierans M, Gadd GM (2010). Rock-building fungi. Geomicrobiol J 27: 624-629

Fonseca AJ, Pina F, Macedo MF, Leal N, Romanowska-Deskins A, Laiz L, Gómez-Bolea A, SaizJimenez C (2010). Anatase as an alternative application for preventing biodeterioration of mortars: evaluation and comparison with other biocides. Int Biodeterior Biodegrad 64: 388-396 Fry EJ (1924). A suggested explanation of the mechanical action of lithophytic lichens on rocks (shale). Ann Bot 38: 175-196 
Fry, EJ (1927). The mechanical action of crustaceous lichens on substrata of shale, schist, gneiss, limestone, and obsidian. Ann Bot 41: 437-460

Gadd GM (2017). Fungi, rocks, and minerals. Elements 13: 171-176

Gadd GM, Bahri-Esfahani J, Li Q, Rhee YJ, Wei Z, Fomina M, Liang X. (2014). Oxalate production by fungi: significance in geomycology, biodeterioration and bioremediation. Fungal Biol Rev 28: 36-55

Gadd GM, Dyer TD (2017). Bioprotection of the built environment and cultural heritage. Microb Biotechnol 10: 1152-1156

Garcia-Vallès M, Topal T, Vendrell-Saz M (2003). Lichenic growth as a factor in the physical deterioration or protection of Cappadocian monuments. Environ Geol 43: 776-781

Garty J (1990). Influence of epilithic microorganisms on the surface temperature of building walls. Can J Bot 68: 1349-1353

Garvie LA, Knauth LP, Bungartz F, Klonowski S, Nash TH (2008). Life in extreme environments: survival strategy of the endolithic desert lichen Verrucaria rubrocincta. Naturwissenschaften 95: $705-712$

Gazzano C, Favero-Longo SE, Matteucci E, Piervittori R (2011) Index of Lichen Potential Biodeteriogenic Activity: towards a statistical validation and the extension to other biodeteriogens. In: Book of abstract of the XV International Biodeterioration \& Biodegradation Symposium (IBBS-15), 20-23 Sepetember 2011, Vienna (Austria). p. 104

Gazzano C, Favero-Longo SE, Matteucci E, Roccardi A, Piervittori R (2009). Index of Lichen Potential Biodeteriogenic Activity (LPBA): a tentative tool to evaluate the lichen impact on stonework. Intl Biodeterior Biodegrad 63: 836-843

Gómez-Bolea A, Llop E, Ariño X, Saiz-Jimenez C, Bonazza A, Messina P, Sabbioni C (2012). Mapping the impact of climate change on biomass accumulation on stone. J Cult Herit 13: 254258 
Gorbushina AA, Broughton WJ (2009). Microbiology of the atmosphere-rock interface: how biological interactions and physical stresses modulate a sophisticated microbial ecosystem. Ann Rev Microbiol 63: 431-450

Guglielmin M, Favero-Longo SE, Cannone N, Piervittori R, \& Strini A (2011). Role of lichens in granite weathering in cold and arid environments of continental Antarctica. Geol Soc Spec Publ 354: $195-204$

Guillitte O (1995). Bioreceptivity: a new concept for building ecology studies. Sci Total Environ 167: $215-220$

Gümbel CW (1856) Mittheilungen über die neue Färberflechte Lecanora ventosa Ach., nebst Beitrag zur Entwicklungsgeschichte der Flechten. Denkschriften der MathematischNaturwissenschaftlichen Classe Der Kaiserlichen Akademie der Wissenschaften Besonders Abgedruckt 11. Kaiserlich-Königijchen Hof- und Staatsdruckhrei, Wien Haas JR, Purvis OW (2006). Lichen biogeochemistry. In: Gadd GM (ed) Fungi in biogeochemical cycles. Cambridge University Press, Cambridge, pp. 344-376

Hueck HJ (1965). The biodeterioration of materials as a part of hylobiology. Material und Organismen 1: 5-34

Huyssen A (2006). Nostalgia for ruins. Grey Room 23: 6-21

Italian Ministry for Cultural Heritage and Activities (2004) Legislative Decree no. 42 of 22 January 2004 - Code of the Cultural and Landscape Heritage, pursuant to article 10 of law no. 137 of 6 July 2002. https://whc.unesco.org/document/155711. Accessed 3 April 2020

Kakakhel MA, Wu F, Gu JD, Feng H, Shah K, Wang W (2019). Controlling biodeterioration of cultural heritage objects with biocides: A review. Int Biodeterior Biodegrad 143: 104721

Kampf G (2018). Adaptive microbial response to low-level benzalkonium chloride exposure. J of Hosp Infect 100, e1-e22 
Kim M, Weigand MR, Oh S, Hatt JK, Krishnan R, Tezel U, Pavlostathis SG, Konstantinidis KT (2018). Widely used benzalkonium chloride disinfectants can promote antibiotic resistance. Appl Environ Microbiol 84: e01201-18

Krumbein WE (1968). Zur Frage der biologischen Verwitterung: Einfluß der Mikroflora auf die Bausteinverwitterung und ihre Abhängigkeit von edaphischen Faktoren. Z allg Mikrobiol 8: 107117

Lee MR, Parsons I (1999). Biomechanical and biochemical weathering of lichen-encrusted granite: textural controls on organic-mineral interactions and deposition of silica-rich layers. Chem Geol 161: $385-397$

Löki V, Deák B, Lukács AB, Molnár VA (2019). Biodiversity potential of burial places-a review on the flora and fauna of cemeteries and churchyards. Glob Ecol Conserv: e00614

Maguregui M, Knuutinen U, Trebolazabala J, Morillas H, Castro K, Martinez-Arkarazo I, Madariaga JM (2012). Use of in situ and confocal Raman spectroscopy to study the nature and distribution of carotenoids in brown patinas from a deteriorated wall painting in Marcus Lucretius House (Pompeii). Anal Bioanal Chem 402: 1529-1539

Mandrioli P, Caneva G, Sabbioni C (2003). Cultural heritage and aerobiology. Methods and measurement techniques for biodeterioration monitoring. Kluwer Academic Publishers, Dordrecht Mapelli F, Marasco R, Balloi A, Rolli E, Cappitelli F, Daffonchio D, Borin S (2012). Mineralmicrobe interactions: biotechnological potential of bioweathering. J Biotechnol 157: 473-481

Marques J, Gonçalves J, Oliveira C, Favero-Longo SE, Paz-Bermúdez G, Almeida R, Prieto B (2016). On the dual nature of lichen-induced rock surface weathering in contrasting microenvironments. Ecol 97: 2844-2857

Marvasi M, Cavalieri D, Mastromei G, Casaccia A, Perito B (2019). Omics technologies for an indepth investigation of biodeterioration of cultural heritage. Int Biodeterior Biodegrad 144: 104736 Matteucci E, Scarcella AV, Croveri P, Marengo A, Borghi A, Benelli C, Hamdan O, Favero-Longo SE (2019). Lichens and other lithobionts on the carbonate rock surfaces of the heritage site of the 
tomb of Lazarus (Palestinian territories): diversity, biodeterioration, and control issues in a semiarid environment. Ann Microbiol 69: 1033-1046

McCarroll D, Viles H (1995). Rock-weathering by the lichen Lecidea auriculata in an arctic alpine environment. Earth Surf Process Landf 20: 199-206

McIlroy de la Rosa JP, Warke PA, Smith BJ (2012). Lichen-induced biomodification of calcareous surfaces: bioprotection versus biodeterioration. Prog Phys Geogr 37: 325-351

Mcllroy de la Rosa JP, Warke PA, Smith BJ (2014). The effects of lichen cover upon the rate of solutional weathering of limestone. Geomorphol 220: 81-92

Miller AZ, Sanmartín P, Pereira-Pardo L, Dionísio A, Sáiz-Jiménez C, Macedo MF, Prieto B (2012). Bioreceptivity of building stones: a review. Sci Total Environ 426: 1-12

Molina E, Cultrone G, Sebastian E, Alonso FJ (2013). Evaluation of stone durability using a combination of ultrasound, mechanical and accelerated aging tests. J Geophys Eng 10: 035003

Morando M, Wilhelm K, Matteucci E, Martire L, Piervittori R, Viles HA, Favero-Longo SE (2017). The influence of structural organization of epilithic and endolithic lichens on limestone weathering. Earth Surf Process Landf 42: 1666-1679

Mottershead D, Lucas G (2000). The role of lichens in inhibiting erosion of a soluble rock. Lichenol 32: 601-609

Nascimbene J, Salvadori O, Nimis PL (2009). Monitoring lichen recolonization on a restored calcareous statue. Sci Total Environ 407: 2420-2426

Negi A, Sarethy IP (2019). Microbial biodeterioration of Cultural Heritage: Events, colonization, and analyses. Microb Ecol 78: 1014-1029

Nimis PL, Monte M, Tretiach M (1987). Flora e vegetazione lichenica di aree archeologiche del Lazio. Studia Geobotanica 7: 3-161

Nimis PL, Pinna D, Salvadori O (1992). Licheni e Conservazione dei Monumenti. Cooperativa Libraria Universitaria Editrice, Bologna 
Ortega-Morales O, Guezennec J, Hernandez-Duque G, Gaylarde CC, Gaylarde PM (2000).

Phototrophic biofilms on ancient Mayan buildings in Yucatan, Mexico. Curr Microbiol 40: 81-85

Özvan A, Dinçer İ, Akın M, Oyan V, Tapan M (2015). Experimental studies on ignimbrite and the effect of lichens and capillarity on the deterioration of Seljuk Gravestones. Eng Geol 185: 81-95

Pawlik Ł, Phillips JD, Šamonil P (2016). Roots, rock, and regolith: Biomechanical and biochemical weathering by trees and its impact on hillslopes - A critical literature review. Earth Sci Rev 159: $142-159$

Pena-Poza J, Ascaso C, Sanz M, Pérez-Ortega S, Oujja M, Wierzchos J, Souza-Egipsy V, Cañamares MV, Urizal M, Castillejo M, García-Heras M (2018). Effect of biological colonization on ceramic roofing tiles by lichens and a combined laser and biocide procedure for its removal. Int Biodeterior Biodegrad 126: 86-94

Piervittori R, Favero-Longo SE, Gazzano C (2009). Lichens and biodeterioration of stonework: a review. Chimica oggi-Chem Today 27: 8-11

Piñar G, Sterflinger K (2018). Two decades using molecular techniques to study biodeterioration of cultural heritage: An amazing biotechnological development. In: Mosquera MJ, Almoraima Gil ML (eds) Conserving Cultural Heritage: Proceedings of the 3rd International Congress on Science and Technology for the Conservation of Cultural Heritage (TechnoHeritage 2017), May 21-24, 2017, Cadiz, Spain. CRC Press, Boca Raton, pp. 299-302

Pinheiro AC, Mesquita N, Trovão J, Soares F, Tiago I, Coelho C, Paiva de Carvalho H, Gil F, Catarino L, Piñar G, Portugal A (2019). Limestone biodeterioration: A review on the Portuguese cultural heritage scenario. J Cult Herit 36: 275-285

Pinna D (2014) Biofilms and lichens on stone monuments: Do they damage or protect? Front Microbiol 5: 1-3

Pinna D (2017) Coping with biological growth on stone heritage objects: methods, products, applications, and perspectives. Apple Academic Press, Oakville 
Pinna D, Galeotti M, Perito B, Daly G, Salvadori B (2018). In situ long-term monitoring of recolonization by fungi and lichens after innovative and traditional conservative treatments of archaeological stones in Fiesole (Italy). Int Biodeterior Biodegrad 132: 49-58

Pinna D, Salvadori O, Tretiach M (1998). An anatomical investigation of calcicolous endolithic lichens from the Trieste karst (NE Italy). Plant Biosyst 132: 183-195

Pokharel R, Gerrits R, Schuessler JA, Floor GH, Gorbushina AA., von Blanckenburg F (2017). Mg isotope fractionation during uptake by a rock-inhabiting, model microcolonial fungus Knufia petricola at acidic and neutral pH. Environ Sci Technol 51: 9691-9699

Poursat BA, van Spanning RJ, de Voogt P, Parsons JR (2019). Implications of microbial adaptation for the assessment of environmental persistence of chemicals. Crit Rev Environ Sci Technol 49: 2220-2255

Pozo-Antonio JS, Barreiro P, González P, Paz-Bermúdez G (2019). Nd: YAG and Er: YAG laser cleaning to remove Circinaria hoffmanniana (Lichenes, Ascomycota) from schist located in the Côa Valley Archaeological Park. Int Biodeterior Biodegrad 144: 104748

Prieto B, Aira N, Silva B (2007). Comparative study of dark patinas on granitic outcrops and buildings. Sci Total Environ 381: 280-289

Prieto B, Vázquez-Nion D, Fuentes E, Durán-Román AG (2020). Response of subaerial biofilms growing on stone-built cultural heritage to changing water regime and $\mathrm{CO}_{2}$ conditions. Int Biodeterior Biodegrad 148: 104882

Rampazzi L (2019). Calcium oxalate films on works of art: A review. J Cult Herit 40: 195-214

Ricci S, Altieri A (2008). Il ruolo delle briofite nel deterioramento dei Beni Culturali. In: Aleffi M (ed) Biologia ed ecologia delle Briofite. Antonio Delfino, Roma, pp. 417-434

Riminesi C, Olmi R (2016). Localized microwave heating for controlling biodeteriogens on cultural heritage assets. Int J Conserv Sci 7(Special Issue 1): 281-294

Rivas T, Pozo-Antonio JS, de Silanes ML, Ramil A, López AJ (2018). Laser versus scalpel cleaning of crustose lichens on granite. Appl Surf Sci 440: 467-476 
Sáiz-Jiménez C, García Rowe J, Rodríguez Hidalgo JM (1991). Biodeterioration of polychrome Roman mosaics. Int Biodeterior Biodegrad 28: 65- 79

Salvadori O, Charola AE (2011). Methods to prevent biocolonization and recolonization: an overview of current research for architectural and archaeological heritage. In: Charola AE, McNamara C, Koestler RJ (eds) Biocolonization of stone: Control and preventive methods. Proceedings from the MCI Workshop Series. Smithsonian Contributions to Museum Conservation (Vol 2). Smithsonian Inst. Press, Washington, pp. 37-50

Salvadori O, Casanova-Municchia A (2016). The role of fungi and lichens in the biodeterioration of stone monuments. Open Conf Proc J 7 (suppl. 1: M4): 39-54

Sanmartín P, DeAraujo A, Vasanthakumar A (2018). Melding the old with the new: trends in methods used to identify, monitor, and control microorganisms on cultural heritage materials. Microb Ecol 76: 64-80.

Sanmartín P, Rodríguez A, Aguiar U (2020). Medium-term field evaluation of several widely used cleaning-restoration techniques applied to algal biofilm formed on a granite-built historical monument. Int Biodeterior Biodegrad 147: 104870

Sanmartín P, Vázquez-Nion D, Arines J, Cabo-Domínguez L, Prieto B (2017). Controlling growth and colour of phototrophs by using simple and inexpensive coloured lighting: A preliminary study in the Light4Heritage project towards future strategies for outdoor illumination. Int Biodeterior Biodegrad 122: 107-115

Sanz M, Oujja M, Ascaso C, Pérez-Ortega S, Souza-Egipsy V, Fort R, de los Ríos A, Wierzchos J, Cañamares MV, Castillejo M (2017). Influence of wavelength on the laser removal of lichens colonizing heritage stone. Appl Surf Sci 399: 758-768

Sazanova KV, Vlasov DY, Osmolovskay NG, Schiparev SM, Rusakov AV (2016). Significance and regulation of acids production by rock-inhabited fungi. In: Frank-Kamenetskaya OV, Panova EG, Vlasov DY (eds) Biogenic - abiogenic interactions in natural and anthropogenic systems. Springer, Cham, pp. 379-392 

(2012). Role of lichens in weathering of granodiorite in the Sila uplands (Calabria, southern Italy). Sediment Geol 280: 119-134

Scheerer S, Ortega-Morales O, Gaylarde C (2009). Microbial deterioration of stone monuments - an updated overview. Adv Appl Microbiol 66: 97-139

Schröder V, Turcanu-Carutiu D, Honcea A, Ion RM (2019). Microscopical methods for the in situ investigation of biodegradation on Cultural Heritage. In: Turcanu-Carutiu D, Ion RM, Hmood K (eds) Advanced methods and new materials for Cultural Heritage preservation. IntechOpen, 10.5772/intechopen.77505

Schumacher J, Gorbushina A (2020). Light sensing in plant-and rock-associated black fungi. Fungal Biol. In press (https://doi.org/10.1016/j.funbio.2020.01.004)

Seaward MRD(2015). Lichens as agents of biodeterioration. In: Upreti DK, Divakar PK, Shukla V, Bajpai R (eds), Recent advances in Lichenology. Modern methods and approaches in biomonitoring and bioprospection (Vol 1). Springer India, New Delhi, pp. 189-211

Seiffert F, Bandow N, Kalbe U, Milke R, Gorbushina AA (2016). Laboratory tools to quantify biogenic dissolution of rocks and minerals: a model rock biofilm growing in percolation columns.

\section{Front Earth Sci 4: 31}

Shraddha G, Darshan M (2019). Microbially induced calcite precipitation through urolytic organisms - A review. Int J Life Sci 7: 133-139

Sierra-Fernandez A, Gomez-Villalba LS, Rabanal ME, Fort R (2017). New nanomaterials for applications in conservation and restoration of stony materials: A review. Materiales de Construcción 67: 107

Signorini MA (1996) L'Indice di Pericolosità: un contributo del botanico al controllo della vegetazione infestante nelle aree monumentali. Inf Bot Ital 28: 7-14

Silverman MP (1979). Biological and organic chemical decomposition of silicates. Stud Environl Sci 3: $445-465$ 
Slater JW (1856) On some reactions of oxalic acid. Chem Gaz 14: 130-131

Smith AL (1921). Lichens. Cambridge University Press, Cambridge

Sohrabi M, Favero-Longo SE, Pérez-Ortega S, Ascaso C, Haghighat Z, Talebian MH, Fadaei H, de los Ríos A (2017). Lichen colonization and associated deterioration processes in Pasargadae, UNESCO world heritage site, Iran. Int Biodeterior Biodegrad 117: 171-182

Sollas WJ (1880) On the activity of a lichen on limestone. Report of the British Association for the Advancement of Science, 586

Souza-Egipsy V, Wierzchos J, Sancho C, Belmonte A, Ascaso C (2004). Role of biological soil crust cover in bioweathering and protection of sandstones in a semi-arid landscape (Torrollones de Gabarda, Huesca, Spain). Earth Surf Process Landf 29: 1651-1661

Stanford C (2000) On preserving our ruins. J Archit Conserv 6: 28-43

Steinbauer MJ, Gohlke A, Mahler C, Schmiedinger A, Beierkuhnlein C (2013) Quantification of wall surface heterogeneity and its influence on species diversity at medieval castles-implications for the environmentally friendly preservation of cultural heritage. J Cult Herit 14: 219-228

Sterflinger K (2010). Fungi: their role in deterioration of cultural heritage. Fungal Biol Rev 24: 4755

Sterflinger K, Krumbein WE (1997). Dematiaceous fungi as a major agent for biopitting on Mediterranean marbles and limestones. Geomicrobiol J 14: 219-230

Sterflinger K, Little B, Pinar G, Pinzari F, de los Ríos A, Gu JD (2018). Future directions and challenges in biodeterioration research on historic materials and cultural properties. Int Biodeterior Biodegrad 129: 10-12

Sternberg T, Viles HA, Cathersides A, Edwards M (2010). Dust particulate absorption by ivy (Hedera helix L) on historic walls in urban environments. Sci Total Environ 409: 162-168 Stupar M, Grbić ML, Džamić A, Unković N, Ristić M, Jelikić A, Vukojević J (2014). Antifungal activity of selected essential oils and biocide benzalkonium chloride against the fungi isolated from cultural heritage objects. S Afr J Bot 93: 118-124 
Taylor-George S, Palmer F, Staley JT, Borns DJ, Curtiss B, Adams JB (1983). Fungi and bacteria involved in desert varnish formation. Microb Ecol 9: 227-245

Tonon C, Favero-Longo SE, Matteucci E, Piervittori R, Croveri P, Appolonia L., Meirano V, Serina M, Elia D (2019). Microenvironmental features drive the distribution of lichens in the House of the Ancient Hunt, Pompeii, Italy. Int Biodeterior Biodegrad 136: 71-81

Totsche KU, Rennert T, Gerzabek MH, Kögel-Knabner I, Smalla K, Spiteller M, Vogel HJ (2010). Biogeochemical interfaces in soil: The interdisciplinary challenge for soil science. J Plant Nutr Soil Sci 173: 88-99

Tratebas AM (2004) Biodeterioration of Prehistoric rock art and issues in site preservation. In: Seaward MRD, St. Clair LL (eds) Biodeterioration of stone surfaces. Springer, Dordrecht, pp. $195-228$

Tretiach M, Bertuzzi S, Candotto Carniel F (2012). Heat shock treatments: a new safe approach against lichen growth on outdoor stone surfaces. Environ Sci Technol 46: 6851-6859

Tretiach M, Bertuzzi S, Salvadori O (2010). Chlorophyll a fluorescence as a practical tool for checking the effects of biocide treatments on endolithic lichens. Int Biodeterior Biodegrad 64: $452-460$

Trovão J, Portugal A, Soares F, Paiva DS, Mesquita N, Coelho C, Pinheiro C, Catarino L, Gil F, Tiago I (2019). Fungal diversity and distribution across distinct biodeterioration phenomena in limestone walls of the old cathedral of Coimbra, UNESCO World Heritage Site. Int Biodeterior Biodegrad 142: 91-102

Uloth W (1861) Beiträge zur Flora der Laubmoose und Flechten von Kurhessen. Flora 44: 565-576 UNESCO (2014). Culture, creativity and sustainable development. Research, innovation, opportunities. Florence declaration - 4 October 2014. https://unesdoc.unesco.org/ark:/48223/pf0000230394. Accessed 03 April 2020 
Valkó O, Tóth K, Kelemen A, Miglécz T, Radócz S, Sonkoly J, Tóthmérész B, Török P, Deák B (2018). Cultural heritage and biodiversity conservation-plant introduction and practical restoration on ancient burial mounds. Nat Conserv 24: 65-80

Vannini A, Contardo T, Paoli L, Scattoni M, Favero-Longo SE, Loppi S (2018). Application of commercial biocides to lichens: Does a physiological recovery occur over time? Int Biodeterior Biodegrad 129: 189-194

Vázquez-Nion D, Silva B, Prieto B (2018). Bioreceptivity index for granitic rocks used as construction material. Sci Total Environ 633: 112-121

Viles H (2019). Biogeomorphology: Past, present and future. Geomorphol. In press (https://doi.org/10.1016/j.geomorph.2019.06.022)

Viles HA, Cutler NA (2012). Global environmental change and the biology of heritage structures. Glob Chang Biol 18: 2406-2418

Viles HA, Goudie AS (2004). Biofilms and case hardening on sandstones from Al-Quwayra, Jordan. Earth Surf Process Landf 29: 1473-1485

Villa F, Pitts B, Lauchnor E, Cappitelli F, Stewart PS (2015). Development of a laboratory model of a phototroph-heterotroph mixed-species biofilm at the stone/air interface. Front Microbiol 6: 1251 Villa F, Stewart PS, Klapper I, Jacob JM, Cappitelli F (2016). Subaerial biofilms on outdoor stone monuments: changing the perspective toward an ecological framework. Bioscience 66: 285-294

Wang J, Ersan YC, Boon N, De Belie N (2016). Application of microorganisms in concrete: a promising sustainable strategy to improve concrete durability. Appl Microbiol Biotechnol 100: 2993-3007

Warscheid T, Braams J (2000). Biodeterioration of stone: a review. Int Biodeterior Biodegrad 46: 343-368

Weber B, Scherr C, Bicker F, Friedl T, Büdel B (2011). Respiration-induced weathering patterns of two endolithically growing lichens. Geobiol 9: 34-43 
921 Wei Z, Kierans M, Gadd GM (2012). A model sheet mineral system to study fungal bioweathering 922 of mica. Geomicrobiol J 29: 323-331

923 Wessels S, Ingmer H (2013). Modes of action of three disinfectant active substances: a review. 924 Regul Toxicol Pharmacol 67: 456-467

925 Wilhelm K, Viles H, Burke O, Mayaud J (2016). Surface hardness as a proxy for weathering 926 behaviour of limestone heritage: a case study on dated headstones on the Isle of Portland, UK. $927 \quad$ Environ Earth Sci 75: 931

928 Zhang G, Gong C, Gu J, Katayama Y, Someya T, Gu JD (2019). Biochemical reactions and 929 mechanisms involved in the biodeterioration of stone world cultural heritage under the tropical 930 climate conditions. Int Biodeterior Biodegrad 143: 104723 
933 Table 1 - Biodeteriorative and bioprotective roles often reported (•) or hypothesized/debated (?) for

934 various types of lithobiontic organisms. It is worth noting that each potential role has to be

935 considered species-specific and cannot be generalized for all the members of each group.

\begin{tabular}{|c|c|c|c|c|c|c|c|c|c|}
\hline & & & & \multirow{2}{*}{$\begin{array}{l}\text { Higher } \\
\text { plants }\end{array}$} & \multirow[b]{2}{*}{ Bryophytes } & \multirow[b]{2}{*}{ Lichens } & \multicolumn{3}{|c|}{ Microbial biofilms } \\
\hline & & & & & & & Algae & Cyanobacteria & $\begin{array}{l}\text { Microcolonial } \\
\text { fungi }\end{array}$ \\
\hline \multirow{7}{*}{$\begin{array}{c}\text { Biodeteriorative } \\
\text { roles }\end{array}$} & \multirow{6}{*}{$\begin{array}{l}\text { During } \\
\text { life }\end{array}$} & \multirow{3}{*}{ Biogeophysical } & "Rooting" & $\bullet$ & $\bullet$ & $\bullet$ & & & $\bullet$ \\
\hline & & & Wetting/ drying & & & $\bullet$ & $\bullet$ & $\bullet$ & \\
\hline & & & $\begin{array}{l}\text { Enhanced } \\
\text { thermal stresses }\end{array}$ & & $?$ & $\bullet$ & $\bullet$ & $\bullet$ & $\bullet$ \\
\hline & & \multirow[b]{2}{*}{ Biogeochemical } & Biomineralization & & $\bullet$ & $\bullet$ & & $\bullet$ & \\
\hline & & & $\begin{array}{l}\text { Acid/ complex } \\
\text { dissolution }\end{array}$ & $\bullet$ & $\bullet$ & $\bullet$ & $\bullet$ & - & $?$ \\
\hline & & Aesthetic loss & $\begin{array}{l}\text { Surface coverage/ } \\
\text { soiling }\end{array}$ & $\bullet$ & $\bullet$ & $\bullet$ & $\bullet$ & $\bullet$ & $\bullet$ \\
\hline & $\begin{array}{l}\text { After } \\
\text { death }\end{array}$ & $\begin{array}{l}\text { Remnant } \\
\text { biocrusts }\end{array}$ & Disfiguring patina & $?$ & $\bullet$ & $\bullet$ & $\bullet$ & $\bullet$ & $\bullet$ \\
\hline \multirow{7}{*}{$\begin{array}{l}\text { Bioprotective } \\
\text { roles }\end{array}$} & \multirow{6}{*}{$\begin{array}{l}\text { During } \\
\text { life }\end{array}$} & \multirow{3}{*}{ Shielding } & Umbrella effect & $\bullet$ & $\bullet$ & $\bullet$ & $?$ & $?$ & \\
\hline & & & $\begin{array}{l}\text { Reduced thermal } \\
\text { stress }\end{array}$ & $\bullet$ & $\bullet$ & $\bullet$ & $\bullet$ & $?$ & \\
\hline & & & From pollutants & $\bullet$ & $?$ & $?$ & $?$ & $?$ & \\
\hline & & \multirow[t]{2}{*}{ Biogeochemical } & $\begin{array}{l}\text { Rock varnish \& } \\
\text { case hardening }\end{array}$ & & & $\bullet$ & & $\bullet$ & $\bullet$ \\
\hline & & & Biomineralization & & $\bullet$ & $\bullet$ & & $\bullet$ & \\
\hline & & $\begin{array}{c}\text { Aesthetic/ } \\
\text { biodiversity } \\
\text { enhancement }\end{array}$ & 'Greening' walls & $\bullet$ & $\bullet$ & $\bullet$ & $\bullet$ & $\bullet$ & \\
\hline & $\begin{array}{l}\text { After } \\
\text { death }\end{array}$ & $\begin{array}{l}\text { Remnant } \\
\text { biocrusts }\end{array}$ & Protective patina & $?$ & $\bullet$ & $\bullet$ & $\bullet$ & $\bullet$ & $\bullet$ \\
\hline
\end{tabular}




\section{Figure captions}

Fig. 1. Lithobionts on stone cultural heritage. a Residence of the Royal House of Savoy in Govone (Italy; year 2010); b Fushimi Inari-Taisha-Shrine in Kyoto (Japan; 2019); c Sanctuaire de NotreDame de Laghet in La Trinité (France; 2019); d Roman underground cistern down to Lithostrotos in Jerusalem Old Town (2017); e 16th century Kelmscott Manor near Oxford (UK; 2018); f Engravings of the 'Rock of the Map' in Valle Camonica (Italy; 2016); g St Andrew's Churchyard in the Isle of Portland (UK; 2018); h North Grotto Temple in the Gansu province (China; 2018); i The Mostaccini Fountain in the Boboli Gardens of Florence (Italy; 2016).

Fig. 2. Lithobiont-related processes and spatial patterning on CHSS: the example of lichen-forming fungi. a rock flaking associated with lichen colonization of a sandstone (Pietra Serena) sculpted surface. b Pietra Serena colonized by the lichen Aspicilia cinerea (L.) Körb., displaying the thalline component (\#) at the sandstone surface, and the hyphal penetration component $\left(^{*}\right)$ developing along the grain borders (polished cross section stained by PAS and observed under reflected light microscopy; bar: $500 \mu \mathrm{m}$ ); c pitting at the surface of a limestone previously colonized by an endolithic lichen; $\mathbf{d}$ Aurisina limestone colonized by the endolithic lichen Bagliettoa baldensis (A.

Massal.) Vězda, displaying both the photobiont (red) and the mycobiont (green) developing within the substrate, and a pit occupied by a fruiting body $(*)$ (polished cross section stained with FITCConcanavalin A and observed under confocal laser scanning microscopy; bar: $500 \mu \mathrm{m}$ ); e biomineralization of calcium oxalates at the interface between a lichen thallus and a serpentinite rock ${ }^{*}$, cross sectioned hyphae submerged by the oxalates; scanning electron microscopy; bar: 5 $\mu \mathrm{m}$ ); f serpentinite colonized by the lichen Lecidea atrobrunnea (DC.) Schaer., displaying oxalates (milk-like high birefringence colours) in the medulla layer and at the rock interface (thin cross section observed under cross polarized transmitted light; bar: $500 \mu \mathrm{m}$ ).

Fig. 3. Colonization dynamics on CHSS. a lichens on a granite gravestone in the Walser graveyard of the alpine village Gressoney-la-Trinite (Italy; year 2010), b the same surface after cleaning by professional restorers (year 2011); c lichen recolonization after eight years (year 2019). 
964 Fig. 4. Framework summarizing the spheres of knowledge dealing with the lithobiontic colonization 965 of CHSS (white boxes) and the potential control strategies (green), with the related diagnostic 966 approaches (blue). Such knowledge may properly support management decisions (orange) to 967 improve the conservation of stone cultural heritage. 

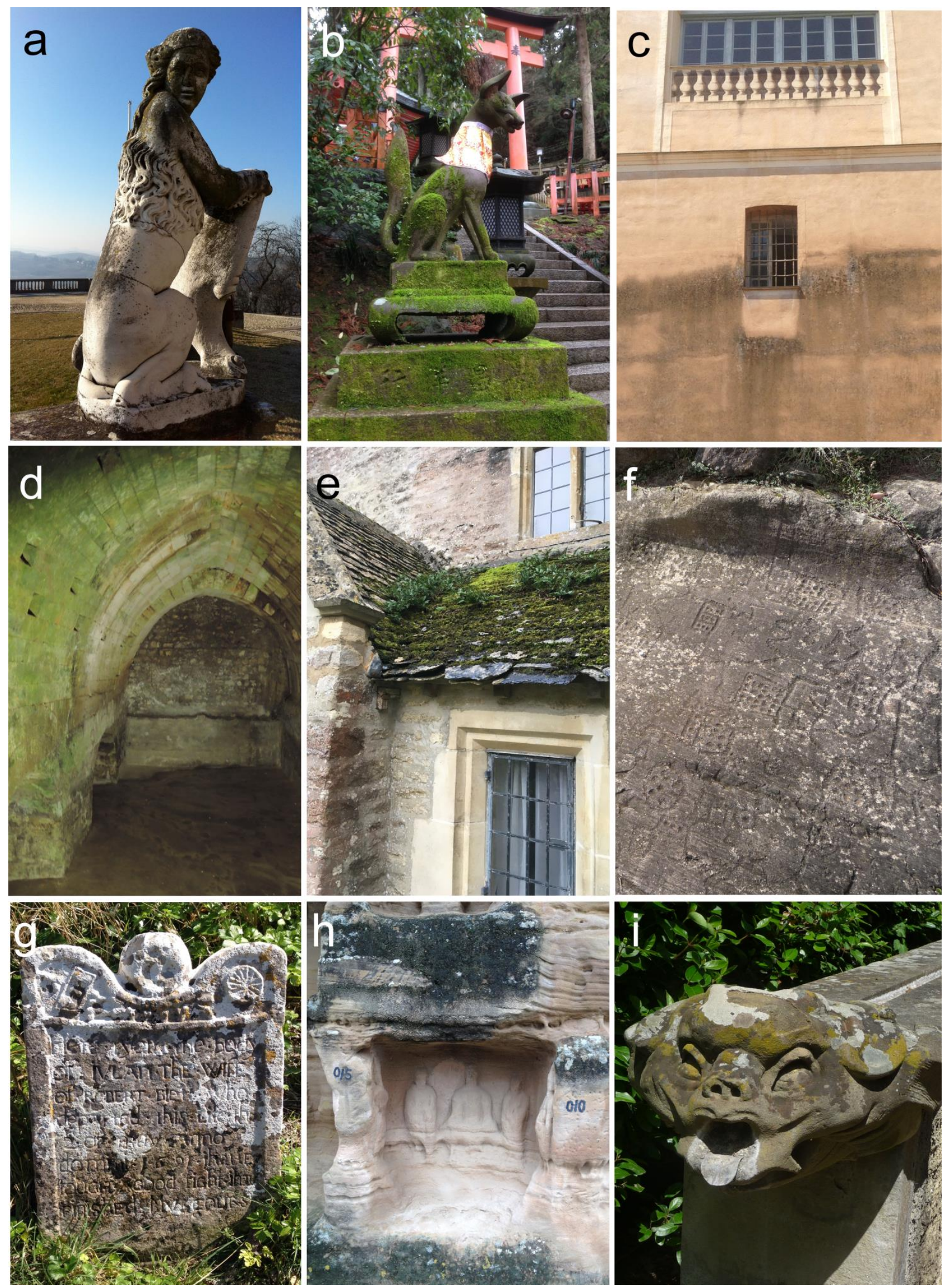


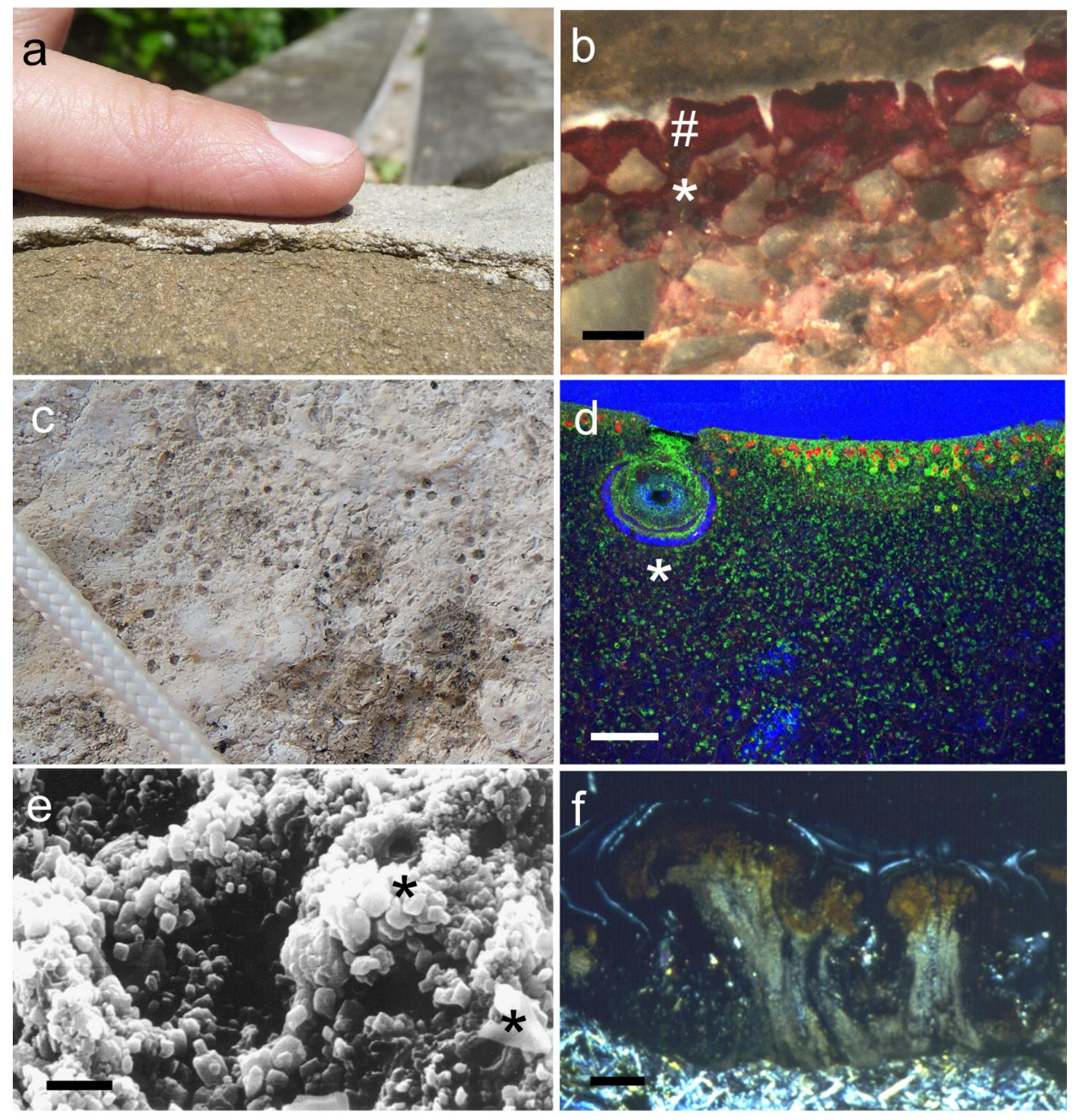



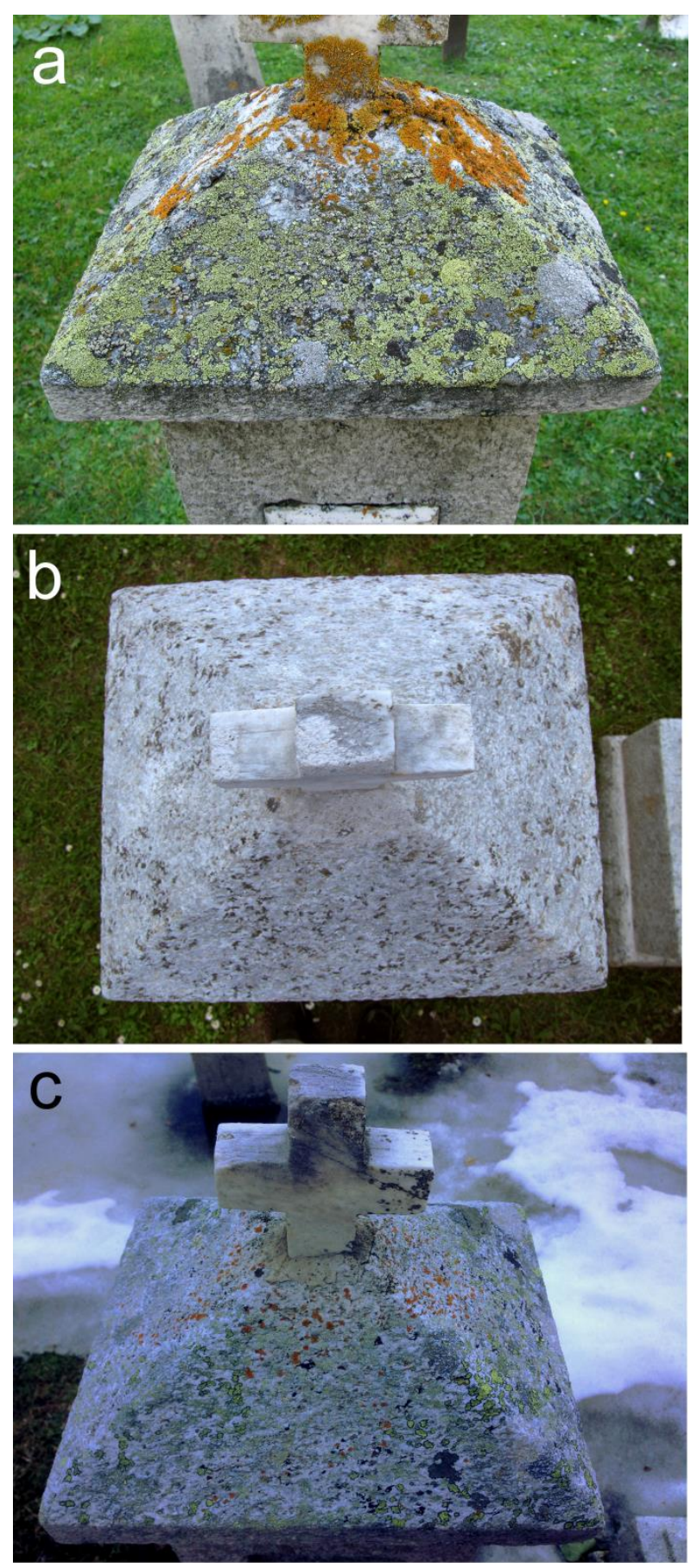


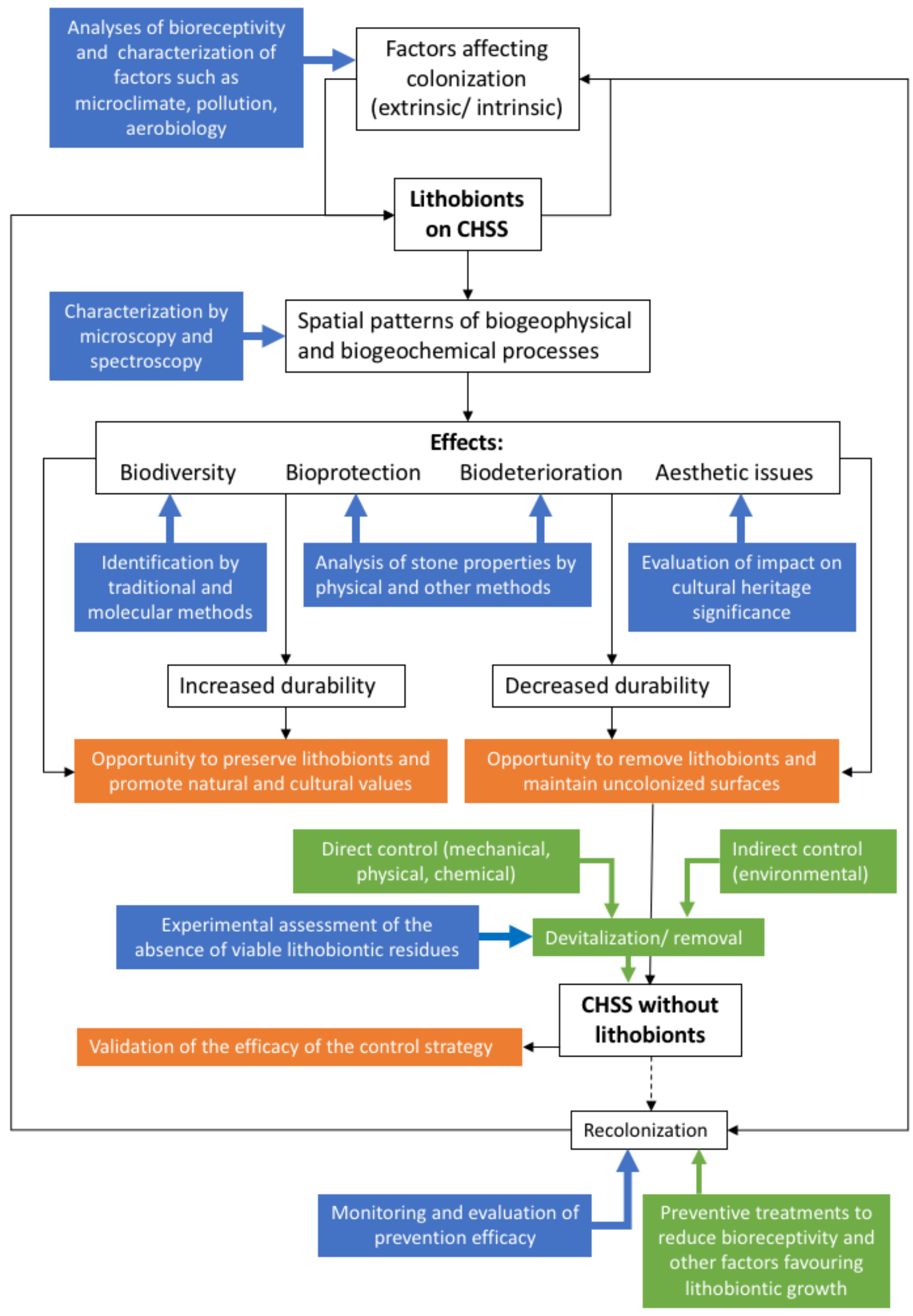

